\title{
Corrigendum to "Usnea Acid as Multidrug Resistance (MDR) Reversing Agent against Human Chronic Myelogenous Leukemia K562/ADR Cells via an ROS Dependent Apoptosis"
}

\author{
Wenjing Wang $\mathbb{D}^{1,2,3}$ Shubin Niu, ${ }^{4}$ Luxin Qiao, ${ }^{1,2,3}$ Feili Wei, ${ }^{1,2,3}$ Jiming Yin, ${ }^{1,2,3}$ \\ Shanshan Wang, ${ }^{1,2,3}$ Yabo Ouyang, ${ }^{1,2,3}$ and Dexi Chen $\mathbb{1}^{1,2,3}$ \\ ${ }^{1}$ Capital Medical University Affiliated Beijing You An Hospital, Beijing 100069, China \\ ${ }^{2}$ Beijing Institute of Hepatology, Beijing 100069, China \\ ${ }^{3}$ Beijing Precision Medicine and Transformation Engineering Technology Research Center of Hepatitis and Liver Cancer, \\ 100069, China \\ ${ }^{4}$ School of Biomedicine, Beijing City University, No. 6 Huanghoudian Road Haidian District, Beijing 100094, China \\ Correspondence should be addressed to Dexi Chen; dexichen@ccmu.edu.cn
}

Received 11 November 2021; Accepted 11 November 2021; Published 22 December 2021

Copyright (c) 2021 Wenjing Wang et al. This is an open access article distributed under the Creative Commons Attribution License, which permits unrestricted use, distribution, and reproduction in any medium, provided the original work is properly cited.

\begin{abstract}
The article titled "Usnea Acid as Multidrug Resistance (MDR) Reversing Agent against Human Chronic Myelogenous Leukemia K562/ADR Cells via an ROS Dependent Apoptosis" [1] contains a figure duplication in Figures 2 and 3, which was raised on PubPeer [2]. Specifically, Figure 2(c) panel UA + Adr overlaps with Figure 3(c) panel UA + Adr. The authors state that this was due to the incorrect file being selected during the preparation of the figure. The correct Figure 3(c) is as below.
\end{abstract}




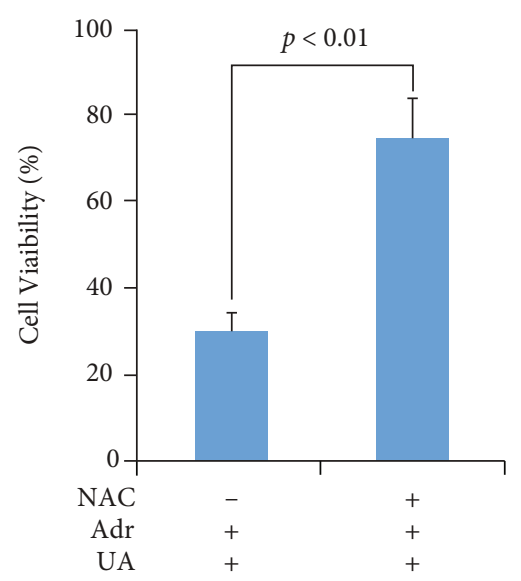

(a)

ROS
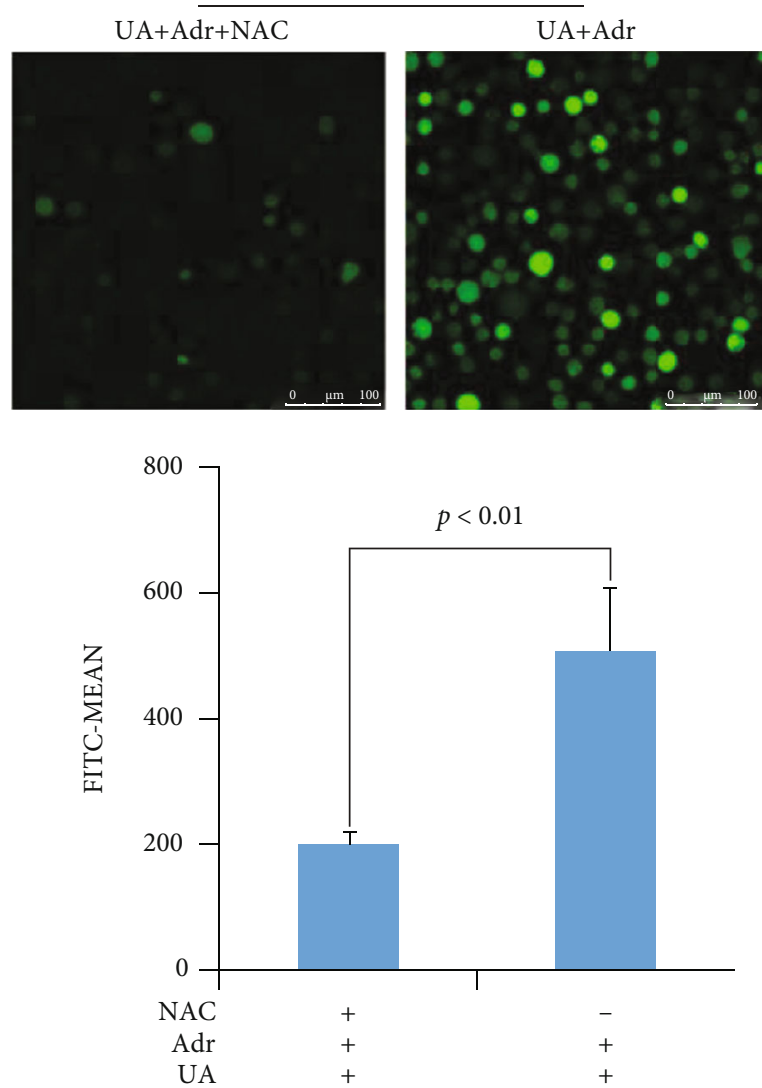

(c)

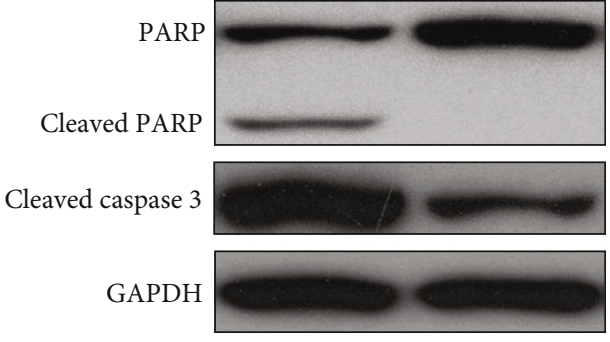

(b)
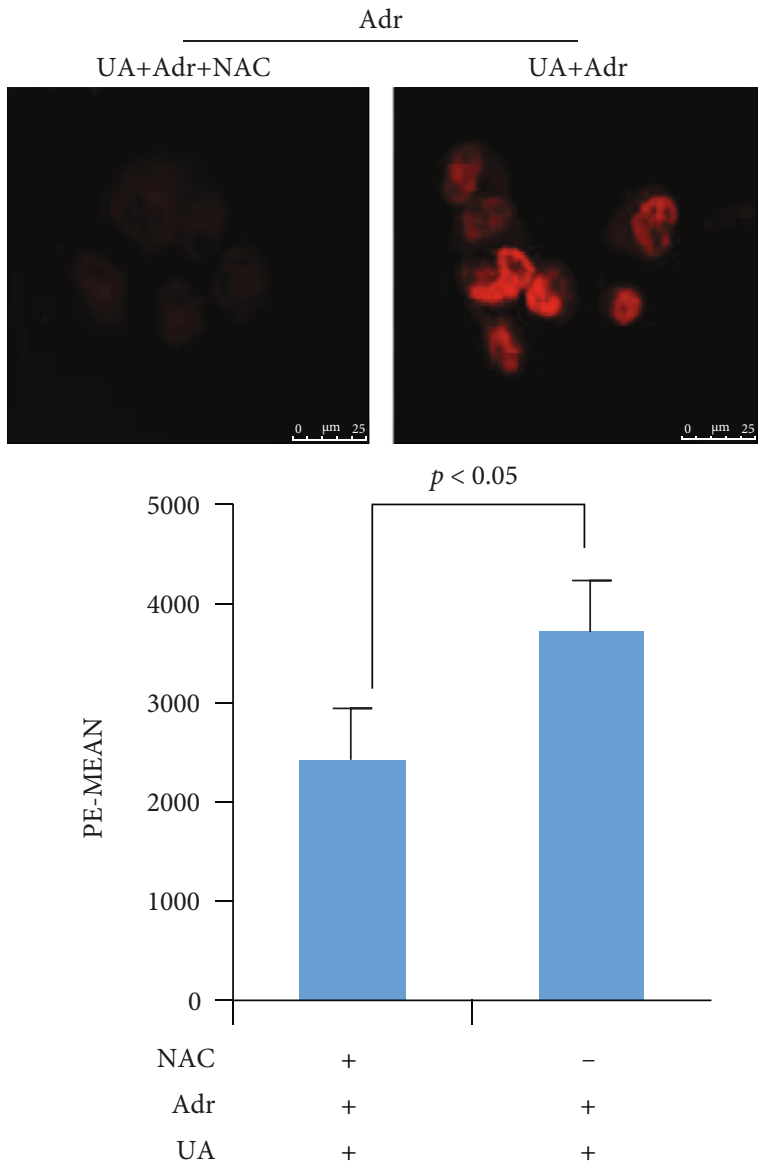

(d)

FiguRe 3

\section{References}

[1] W. Wang, S. Niu, L. Qiao et al., "Usnea Acid as Multidrug Resistance (MDR) Reversing Agent against Human Chronic Myelogenous Leukemia K562/ADR Cells via an ROS Dependent Apoptosis," BioMed Research International, vol. 2019, Article ID 8727935, 7 pages, 2019.
[2] E. M. Bik, "Usnea Acid as Multidrug Resistance (MDR) Reversing Agent against Human Chronic Myelogenous Leukemia K562/ADR Cells via an ROS Dependent Apoptosis," BioMed Research International, vol. 2019, no. 1, 2019. 